MAJOR ARTICLE

\title{
Immunologic Response to Antiretroviral Therapy in Hepatitis C Virus-Coinfected Adults in a Population-Based HIV/AIDS Treatment Program
}

\author{
Paula Braitstein, ${ }^{1,2, a}$ Carlos Zala, ${ }^{5}$ Benita Yip, ${ }^{1}$ Martin W. G. Brinkhof, ${ }^{4}$ David Moore, ${ }^{1}$ Robert S. Hogg, ${ }^{1,2}$ \\ and Julio S. G. Montaner ${ }^{1,3}$ \\ ${ }^{1}$ British Columbia Centre for Excellence in HIV/AIDS and Departments of ${ }^{2}$ Health Care and Epidemiology and ${ }^{3}$ Medicine, University of British \\ Columbia, Vancouver, Canada; ${ }^{4}$ Institute of Social and Preventive Medicine, University of Berne, Berne, Switzerland; ${ }^{5}$ Fundacion Huesped, \\ Buenos Aires, Argentina
}

Background. We sought to characterize the impact that hepatitis $\mathrm{C}$ virus (HCV) infection has on CD4 cells during the first 48 weeks of antiretroviral therapy (ART) in previously ART-naive human immunodeficiency virus (HIV)-infected patients.

Methods. The HIV/AIDS Drug Treatment Programme at the British Columbia Centre for Excellence in HIV/ AIDS distributes all ART in this Canadian province. Eligible individuals were those whose first-ever ART included 2 nucleoside reverse transcriptase inhibitors and either a protease inhibitor or a nonnucleoside reverse transcriptase inhibitor and who had a documented positive result for HCV antibody testing. Outcomes were binary events (time to an increase of $\geqslant 75 \mathrm{CD} 4$ cells $/ \mathrm{mm}^{3}$ or an increase of $\geqslant 10 \%$ in the percentage of CD4 cells in the total T cell population [CD4 cell fraction]) and continuous repeated measures. Statistical analyses used parametric and nonparametric methods, including multivariate mixed-effects linear regression analysis and Cox proportional hazards analysis.

Results. Of 1186 eligible patients, 606 (51\%) were positive and 580 (49\%) were negative for HCV antibodies. $\mathrm{HCV}$ antibody-positive patients were slower to have an absolute $(P<.001)$ and a fraction $(P=.02)$ CD4 cell event. In adjusted Cox proportional hazards analysis (controlling for age, sex, baseline absolute CD4 cell count, baseline pVL, type of ART initiated, AIDS diagnosis at baseline, adherence to ART regimen, and number of CD4 cell measurements), HCV antibody-positive patients were less likely to have an absolute CD4 cell event (adjusted hazard ratio $[\mathrm{AHR}], 0.84$ [95\% confidence interval $\{\mathrm{CI}\}, 0.72-0.98]$ ) and somewhat less likely to have a CD4 cell fraction event (AHR, 0.89 [95\% CI, 0.70-1.14]) than HCV antibody-negative patients. In multivariate mixedeffects linear regression analysis, HCV antibody-negative patients had increases of an average of 75 cells in the absolute CD4 cell count and 4.4\% in the CD4 cell fraction, compared with 20 cells and 1.1\% in HCV antibodypositive patients, during the first 48 weeks of ART, after adjustment for time-updated pVL, number of CD4 cell measurements, and other factors.

Conclusion. HCV antibody-positive HIV-infected patients may have an altered immunologic response to ART.

The use of highly active antiretroviral therapy (HAART) has led to dramatic reductions in HIV-related morbidity and mortality [1-3]. However, parallel with this success has been the subsequent emergence of comorbidities, such as viral hepatitis. Hepatitis $\mathrm{C}$ virus $(\mathrm{HCV})$ is present in $\sim 30 \%$ of HIV-positive patients in the developed

Received 10 November 2004; accepted 8 August 2005; electronically published 7 December 2005.

Reprints or correspondence: Dr. Paula Braitstein, ISPM-University of Berne, Finkenhubelweg 11, CH-3012, Berne, Switzerland (pbraitstein@ispm.unibe.ch).

The Journal of Infectious Diseases 2006; 193:259-68

(C) 2005 by the Infectious Diseases Society of America. All rights reserved. 0022-1899/2006/19302-0012\$15.00 world, and in some populations, such as injection drug users and hemophiliacs, nearly all patients who are infected with HIV are coinfected with HCV [4-7].

Immunologic and virologic responses to antiretroviral therapy (ART) in HCV/HIV-coinfected populations has been examined previously. Most studies have found that HCV infection has no effect on the virologic

Presented in part: International AIDS Society Conference, Paris, France, 13-17 July 2003 (abstract 214); First International Conference on HIV and Hepatitis C Co-infection, Noordwijk aan Zee, The Netherlands, 2-4 December 2004.

Potential conflicts of interest: none reported.

Information on financial support appears in the Acknowledgments section.

a Present affiliation: Institute of Social and Preventive Medicine, University of Berne, Berne, Switzerland. 
response to ART [8-11], but, in the literature, there are conflicting reports regarding the immunologic response $[8-9,11-$ 12]. The data on the immunologic response to ART may be inconsistent for several reasons. First, it can take up to 24 months of treatment for a complete CD4 cell response to occur [13], which is beyond the time frame of many studies. How an increase in the CD4 cell response is measured and defined is another key factor. Indeed, $\mathrm{T}$ cells may become sequestered secondary to HCV infection, and this may potentially affect the consistency between and the interpretability of data on the absolute and fraction $\mathrm{T}$ cell populations $[14,15]$. Immune dysregulation due to both HIV and HCV infection may also lead to an impaired immunologic response, primarily in patients with low baseline CD4 cell counts [8, 9, 11].

The immunologic response to ART in patients coinfected with HIV and HCV is important because of its implications for when to initiate ART. HCV-related hepatic fibrosis progression in HIV-infected patients is strongly associated with a weakened immune system [16], and delaying ART for too long may result in a more-rapid progression of HCV disease-particularly if a patient's immunologic recovery will be only partial. Although treatments for HCV infection are becoming more effective, unfavorable genotypes $[17,18]$, as well as concomitant anemia, depression [16, 19], or HIV infection [20-22], mean that only a limited number of $\mathrm{HIV} / \mathrm{HCV}$-coinfected patients can expect to successfully complete HCV treatment. Thus, ART for HIV is paramount to the health management of these coinfected patients.

The primary objective of the present study was to examine outcomes in the absolute CD4 cell count and the percentage of CD4 cells in the total T cell population during the first 48 weeks of ART in previously ART-naive HCV antibody-positive and $\mathrm{HCV}$ antibody-negative HIV-infected patients in a population-based HIV/AIDS treatment program. Our secondary objective was to describe the contribution of the baseline absolute CD4 cell count to this response.

\section{SUBJECTS, MATERIALS, AND METHODS}

Data source: HIV/AIDS Drug Treatment Programme. Since 1986, antiretroviral drugs have been centrally distributed in British Columbia at no cost to eligible HIV-infected patients. In October 1992, the distribution of antiretroviral drugs became the responsibility of the HIV/AIDS Drug Treatment Programme of the British Columbia Centre for Excellence in HIV/AIDS. This distribution program remains the only free source of antiretroviral drugs in this Canadian province (and it is a unique program in Canada). The HIV/AIDS Drug Treatment Programme has received ethics approval from the University of British Columbia Ethics Review Committee at its St. Paul's Hospital site, and the program conforms with the province's Freedom of Information and Protection of Privacy Act.
The HIV/AIDS Drug Treatment Programme distributes antiretroviral drugs on the basis of specific guidelines generated by the Therapeutic Guidelines Committee [23]. These guidelines are consistent with the treatment guidelines published by the International AIDS Society [13, 24-26]. The HIV/AIDS Drug Treatment Programme's guidelines recommend that CD4 cell counts and plasma HIV-1 RNA loads (pVLs) be monitored at baseline, at 4 weeks after initiation of ART, and every 3 months thereafter. In this program, pVLs are measured using the Amplicor HIV-1 Monitor test (Roche Diagnostics). All classes of federally licensed antiretroviral drugs - including all nucleoside reverse transcriptase inhibitors (NRTIs), nonnucleoside reverse transcriptase inhibitors (NNRTIs), and protease inhibitors (PIs) are presently available through the program. Tenofovir, atazanavir, and enfuvirtide are also available.

Patients are automatically entered into the HIV/AIDS Drug Treatment Programme when they are first prescribed any antiretroviral drug. At entry into the program and with each subsequent physician visit, the patient's history (if any) of antiretroviral drug use, the absolute CD4 cell count, and $\mathrm{pVL}$ are recorded. Typically, patients are followed up at 3-month intervals, at which time prescriptions are renewed or altered on the basis of treatment success and other clinical factors.

Study population. The HAART Observational Medical Evaluation and Research (HOMER) study is a nested cohort within the HIV/AIDS Drug Treatment Programme. It includes all previously ART-naive patients who initiated ART consisting of 2 NRTIs and either a PI or an NNRTI between July 1996 and August 2000. The data used in the present analyses are from patients in the HOMER cohort for whom HCV serological data were available.

Outcome measures. The primary outcome measure for this analysis was the CD4 cell response, measured using both absolute CD4 cell counts and CD4 cells as a percentage of the total $\mathrm{T}$ cell population (referred to throughout this article as "the CD4 cell fraction" and expressed as a percentage), comparing HCV antibody-positive and HCV antibody-negative HIV1-infected patients. Events were defined, respectively, as an increase of $\geqslant 75$ cells $/ \mathrm{mm}^{3}$ in the absolute CD4 cell count or an increase of $\geqslant 10 \%$ in the CD4 cell fraction within the first 48 weeks of treatment. We also examined both absolute and CD4 cell fraction measurements as continuous repeated outcomes throughout the first 48 weeks of ART.

Baseline was defined as the most recent measurement of CD4 cells performed within 180 days before initiation of ART. Baseline characteristics examined were sex, age, CD4 cells (absolute number and fraction), pVL (expressed in $\log _{10}$ copies $/ \mathrm{mL}$ ), whether patients had an AIDS diagnosis, and type of treatment initiated (PI based or NNRTI based). The characteristics were analyzed by comparing $\mathrm{HCV}$ antibody-positive patients with $\mathrm{HCV}$ antibody-negative patients. 
Our definition of adherence to ART was based on the proportion of time that antiretroviral drugs dispensed would last during the first year of follow-up. This calculation was restricted to each patient's first year of ART, to avoid the reverse causation that could occur for patients who ceased ART because they became too sick to take the drugs. We have previously demonstrated that this estimate strongly predicts virologic response [27] and survival $[28,29]$. For the purposes of the present analyses, adherence was treated as a binary variable, where 1 was $\geqslant 95 \%$ adherence to ART, and 0 was $<95 \%$ adherence to ART.

Statistical analyses. We used an intent-to-treat approach whereby all eligible patients were included in the study when they were first dispensed antiretroviral drugs, regardless of whether they later discontinued or modified their regimen. HCV antibody-positive and HCV antibody-negative patients were compared using both parametric and distribution-free methods. Categorical data were analyzed using Pearson's $\chi^{2}$ test. Fisher's exact test was used for contingency tables in which $\geqslant 25 \%$ of the expected cell frequencies were $<5$. Continuous variables were analyzed using the Wilcoxon rank-sum test.

Kaplan-Meier analysis was used to calculate cumulative rates of a increase of $\geqslant 75$ cells $/ \mathrm{mm}^{3}$ in the absolute CD4 cell count or an increase of $\geqslant 10 \%$ in the CD4 cell fraction. In secondary analyses, we stratified the population by baseline absolute CD4 cell count ( $\leqslant 200$ cells $/ \mathrm{mm}^{3},<350$ cells $/ \mathrm{mm}^{3}$, and $\geqslant 350$ cells/ $\mathrm{mm}^{3}$ ). Because of small numbers, the $<350$ cells $/ \mathrm{mm}^{3}$ group included patients with $\leqslant 200$ cells $/ \mathrm{mm}^{3}$. Cox proportional hazards analysis was used to calculate unadjusted and adjusted hazard ratios (AHRs) and 95\% confidence intervals (CIs). Possible confounding factors adjusted for were sex (male vs. female), age at baseline (continuous), AIDS diagnosis at baseline (yes vs. no), absolute CD4 cell count (per $100-$ cell $/ \mathrm{mm}^{3}$ increase) or CD4 cell fraction (per 5\% increase), log-transformed pVL (continuous, per $\log _{10}$ copies/mL), type of treatment initiated (PI vs. NNRTI based), adherence to ART in the first year of treatment ( $\geqslant 95 \%$ vs. $<95 \%$ ), and number of CD4 cell measurements (continuous). In a subanalysis, Cox proportional hazards analysis was conducted using time-updated pVL response, in addition to the aforementioned variables. The assumption of proportional hazards was validated by inspection of $\log _{10}\left(-\log _{10}\right.$ [survival function] $)$ estimates against log time plots.

Multivariate mixed-effects linear regression analysis was performed to model CD4 cell slopes (absolute and fraction) during the first 48 weeks of ART, primarily for the whole population and secondarily stratified by baseline absolute CD4 cell count $\left(\leqslant 200\right.$ cells $/ \mathrm{mm}^{3},<350$ cells $/ \mathrm{mm}^{3}$, and $\geqslant 350$ cells $\left./ \mathrm{mm}^{3}\right)$. Independent fixed effects included were HCV antibody status at baseline (positive vs. negative), time since initiation of ART (weeks), sex (male vs. female), age at baseline, and pVL (categorized as $<500$ copies/mL, 500-20,000 copies/mL, and $>20,000$ copies $/ \mathrm{mL}$ ), and the latter was updated over time. Random effects included were patient identification (ID), time since initiation of ART (weeks), and baseline absolute CD4 cell count (continuous). All patients were included in the multivariate mixed-effects linear regression analysis, regardless of how many CD4 cell measurements they had. The effect of HCV infection over time was measured by creating an interaction term between HCV antibody status and time. Correlation between repeated outcome measures was assumed to be constant, but we tested whether using a time-decaying correlation structure made a difference (it did not). The data were analyzed using SAS (version 6.2; SAS Institute) and Stata (version 9; StataCorp). All reported $P$ values are 2 -tailed.

\section{RESULTS}

Of the 1388 patients in the HOMER cohort, 1186 were available for the present analysis, including 606 (51\%) who were HCV antibody positive and 580 (49\%) who were HCV antibody negative. Those with HCV serological data available were more likely to be male ( $86 \%$ vs. $75 \% ; P<.001$ ), but there was no difference in history of injection drug use $(27 \%$ vs. $27 \% ; P=.92)$, having an AIDS diagnosis at baseline ( $13 \%$ vs. $14 \% ; P=.68)$, median age at baseline (37 vs. 37 years; $P=.51$ ), median baseline absolute CD4 cell count ( 260 vs. 270 cells $/ \mathrm{mm}^{3} ; P=.14$ ), and baseline pVL (5.1 vs. $5.1 \log _{10}$ copies/mL; $P=.36$ ) between the groups.

The baseline characteristics of HCV antibody-positive and HCV antibody-negative patients are summarized in table 1. There were no statistical differences at baseline in the median age, median absolute CD4 cell count, pVL, or type of ART initiated. However, HCV antibody-positive patients were less likely to be male $(78 \%$ vs. $93 \% ; P<.001)$, more likely to have a history of injection drug use $(47 \%$ vs. $6 \% ; P<.001)$, and less likely to have an AIDS diagnosis at baseline (11\% vs. $15 \%$; $P$ $=.028$ ) than HCV antibody-negative patients. In addition, in spite of having the same median absolute CD4 cell count as HCV antibody-negative patients, they had a significantly higher baseline median CD4 cell fraction $(19 \%$ vs. $16 \% ; P<.001)$.

The median time to an increase of $\geqslant 75$ cells $/ \mathrm{mm}^{3}$ in the absolute CD4 cell count was 69 days (interquartile range [IQR], 34-149 days) in HCV antibody-negative patients and 84 days (IQR, 40-171 days) in HCV antibody-positive patients $(P=$ $.05)$. The median time to censoring in the absolute CD4 cell count time-to-event analysis was 197 days (IQR, 0.5-282 days) in HCV antibody-negative patients and 199.5 days (IQR, 0.5279 days) in HCV antibody-positive patients $(P=.93)$. The median time to a CD4 cell fraction event ( $\geqslant 10 \%$ increase) was 151 days (IQR, 58-235 days) in HCV antibody-negative patients and 89.5 days (IQR, 49-207 days) in HCV antibodypositive patients $(P=.05)$. The median time to censoring in the CD4 cell fraction analysis was 269.5 days (IQR, 206.5-307 
Table 1. Baseline characteristics of hepatitis C virus (HCV) antibody-positive and HCV antibody-negative patients in the HIV/AIDS Drug Treatment Programme of the British Columbia Centre for Excellence in HIV/ AIDS.

\begin{tabular}{|c|c|c|c|}
\hline Baseline characteristic & $\begin{array}{c}\mathrm{HCV} \\
\text { antibody-positive } \\
\text { patients } \\
(n=606)\end{array}$ & $\begin{array}{c}\text { HCV } \\
\text { antibody-negative } \\
\text { patients } \\
(n=580)\end{array}$ & $P$ \\
\hline Sex, no. (\%) male & $473(78)$ & $541(93)$ & $<.001$ \\
\hline Age, median (IQR), years & $37.8(32.2-44.0)$ & $36.8(32.0-43.8)$ & .51 \\
\hline AIDS diagnosis, no. (\%) & $65(11)$ & $87(15)$ & .028 \\
\hline \multicolumn{4}{|l|}{ CD4 cells } \\
\hline Absolute count, median (IQR), cells $/ \mathrm{mm}^{3}$ & $280(130-430)$ & $270(130-420)$ & .56 \\
\hline Fraction, median (IQR), \% & $19(11-27)$ & $16(9-24)$ & $<.001$ \\
\hline $\mathrm{pVL}$, median (IQR), $\log _{10}$ copies $/ \mathrm{mL}$ & $5.0(4.6-5.0)$ & $5.0(4.6-5.0)$ & .99 \\
\hline ART initiated, no. (\%) & & & .48 \\
\hline With PI & $417(69)$ & $388(67)$ & \\
\hline With NNRTI & $189(31)$ & $192(33)$ & \\
\hline
\end{tabular}

NOTE. ART, antiretroviral therapy; IQR, interquartile range; NNRTI, nonnucleoside reverse transcriptase inhibitor; PI, protease inhibitor; pVL, plasma viral load.

days) in HCV antibody-negative patients and 244.5 days (IQR, $145-294$ days) in HCV antibody-positive patients $(P<.001)$. $\mathrm{HCV}$ antibody-positive patients had fewer CD4 cell measurements (median, 3 tests [IQR, $2-4$ tests]) performed than did HCV antibody-negative patients (median, 4 tests [IQR, 3-5 tests]), and this was controlled for in adjusted analyses.

Figure 1 displays the results of the Kaplan-Meier analysis examining the effect that HCV infection had on time to an absolute CD4 cell event $(P<.001)$ and a CD4 cell fraction event $(P=.021)$. When patients were stratified by baseline absolute $\mathrm{CD} 4$ cell count, relatively consistent associations were found with the absolute CD4 cell count (for baseline absolute CD4 cell count $\leqslant 200$ cells $/ \mathrm{mm}^{3}, P<.001$; for baseline absolute CD4 cell count $<350$ cells $/ \mathrm{mm}^{3}, P<.001$; and for baseline absolute CD4 cell count $\geqslant 350$ cells $/ \mathrm{mm}^{3}, P=.006$ ), but more variable associations were found with the CD4 cell fraction (for baseline absolute CD4 cell count $\leqslant 200$ cells $/ \mathrm{mm}^{3}, P=.41$; for baseline absolute CD4 cell count $<350$ cells $/ \mathrm{mm}^{3}, P=.70$; and for baseline absolute CD4 cell count $\geqslant 350$ cells $/ \mathrm{mm}^{3}, P=.001$ ).

Adherence to ART, as expected, had a significant effect on outcome. There were $255 \mathrm{HCV}$ antibody-positive patients (42\%) and $420 \mathrm{HCV}$ antibody-negative patients $(72 \%)$ who were $\geqslant 95 \%$ adherent to ART $(P<.001)$. After we restricted the KaplanMeier analysis to patients $\geqslant 95 \%$ adherent to ART, HCV infection had a smaller but statistically significant effect on the absolute CD4 cell count $(P=.024)$, whereas the effect on the CD4 cell fraction was not statistically significant $(P=.73)$. When patients were stratified by baseline absolute CD4 cell count, there was no clear trend in the effect that HCV infection had on either the absolute CD4 cell count (for baseline absolute CD4 cell count $\leqslant 200$ cells $/ \mathrm{mm}^{3}, P=.30$; for baseline absolute CD4 cell count $<350$ cells $/ \mathrm{mm}^{3}, P=.04$; and for baseline ab- solute CD4 cell count $\geqslant 350$ cells $\left./ \mathrm{mm}^{3}, P=.34\right)$ or the CD4 cell fraction (for baseline absolute CD4 cell count $\leqslant 200$ cells/ $\mathrm{mm}^{3}, P=.61$; for baseline absolute $\mathrm{CD} 4$ cell count $<350$ cells/ $\mathrm{mm}^{3}, P=.31$; and for baseline absolute CD4 cell count $\geqslant 350$ cells $\left./ \mathrm{mm}^{3}, P=.07\right)$.

Table 2 summarizes the results of unadjusted and adjusted Cox proportional hazards analyses of the probability of having an immunologic event (table 2). After we controlled for age at baseline (per 10-year increase), sex (male vs. female), having an AIDS diagnosis at baseline (yes vs. no), baseline absolute CD4 cell count (per 100-cell/ $/ \mathrm{mm}^{3}$ increase), pVL (per $\log _{10}$ copies $/ \mathrm{mL}$ ), adherence to ART ( $\geqslant 95 \%$ vs. $<95 \%$ ), type of ART initiated (PI vs. NNRTI), and number of CD4 cell measurements, HCV antibody-positive patients remained less likely than HCV antibody-negative patients to have an increase of $\geqslant 75 \mathrm{cells} / \mathrm{mm}^{3}$ in the absolute CD4 cell count (overall AHR, 0.84 [95\% CI, 0.72-0.98]; $P=.030$ ). The effect that HCV infection had on the probability of having an increase of $\geqslant 10 \%$ in the $\mathrm{CD} 4$ cell fraction was less pronounced, although this difference may have been related to the smaller number of events (AHR, 0.89 [95\% CI, $0.70-1.14] ; P=.36$ ). The effect that the baseline absolute CD4 cell count had on the AHRs by absolute CD4 cell count (baseline absolute CD4 cell count $\leqslant 200$ cells $/ \mathrm{mm}^{3}$ : AHR, 1.00 [95\% CI, 0.66-1.51] $[P=.98]$; baseline absolute CD4 cell count $<350$ cells $/ \mathrm{mm}^{3}$ : AHR, 1.12 [95\% CI, 0.81-1.53] [ $\left.P=.50\right]$; baseline absolute CD4 cell count $\geqslant 350$ cells $/ \mathrm{mm}^{3}$ : AHR, 0.64 [95\% CI, 0.43-0.96] $[P=.031]$ ) and the CD4 cell fraction (baseline absolute CD4 cell count $\leqslant 200$ cells $/ \mathrm{mm}^{3}$ : AHR, $0.68[95 \% \mathrm{CI}$, 0.46-1.01] $[P=.13]$; baseline absolute CD4 cell count $<350$ cells $/ \mathrm{mm}^{3}$ : AHR, 0.77 [95\% CI, 0.56-1.05] [ $P=.056$ ]; baseline absolute CD4 cell count $\geqslant 350$ cells $/ \mathrm{mm}^{3}$ : AHR, $0.97[95 \% \mathrm{CI}$, $0.62-1.50][P=.87])$ was limited. 

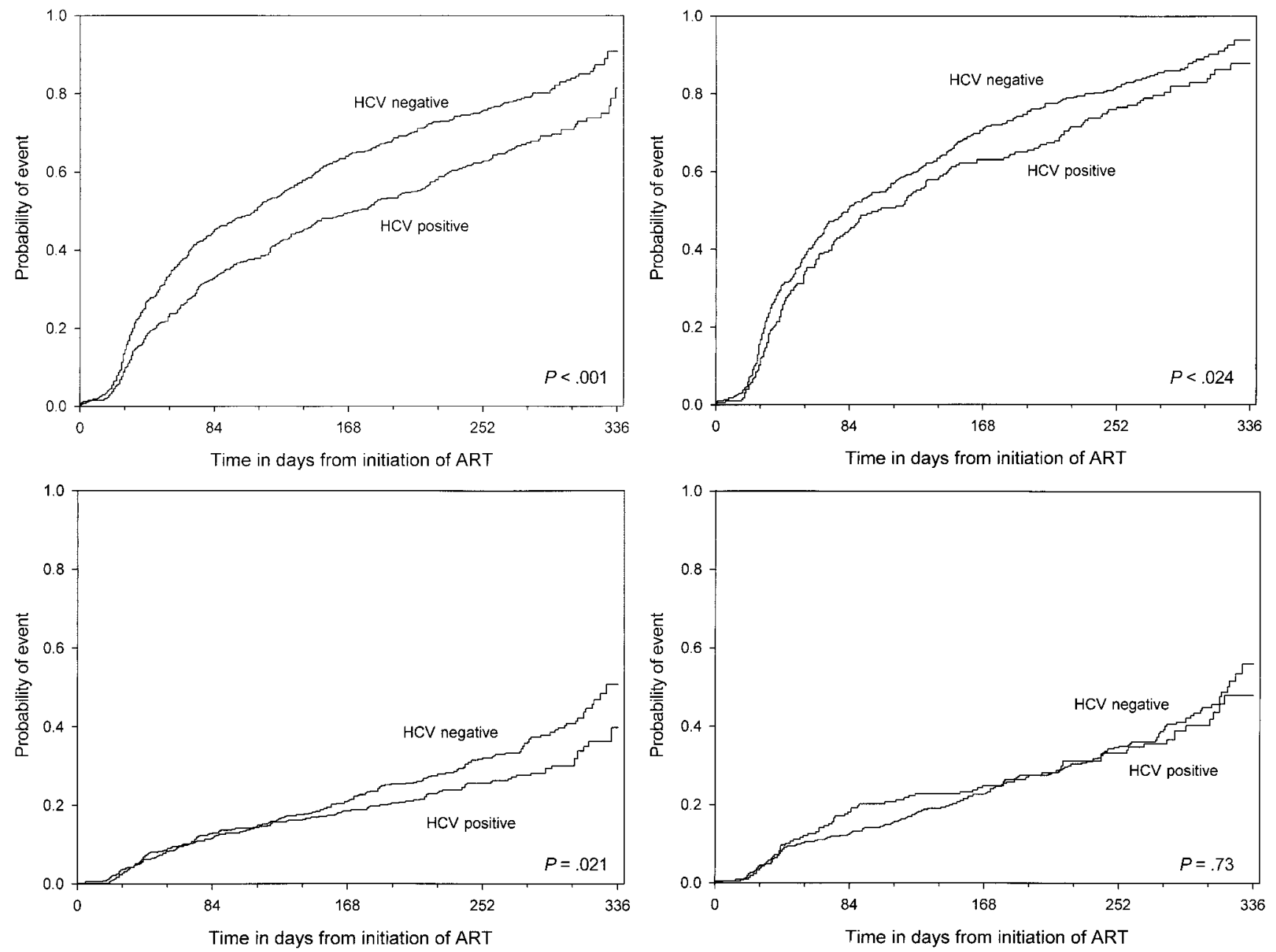

Figure 1. Increases in CD4 cell responses after antiretroviral therapy (ART). $A$, Time to increase of $\geqslant 75$ cells $/ \mathrm{mm}^{3}$ in absolute $\mathrm{CD} 4$ cell count. $B$, Time to increase of $\geqslant 75$ cells $/ \mathrm{mm}^{3}$ in absolute CD4 cell count in patients $>95 \%$ adherent to ART. $C$, Time to increase of $\geqslant 10 \%$ in CD4 cell fraction. $D$, Time to increase of $\geqslant 10 \%$ in CD4 cell fraction in patients $>95 \%$ adherent to ART. HCV, hepatitis C virus.

In a subanalysis, the effect that $\mathrm{HCV}$ infection had on the probability of having an increase of $\geqslant 75$ cells $/ \mathrm{mm}^{3}$ in the absolute CD4 cell count or an increase of $\geqslant 10 \%$ in the CD4 cell fraction was examined in Cox proportional hazards analysis using timeupdated pVL. pVL over time was, as expected, a very strong predictor of having an increase in either the absolute CD4 cell count (AHR, 0.33 [95\% CI, 0.30-0.37]; $P<.001$ ) or the CD4 cell fraction (AHR, 0.36 [95\% CI, 0.30-0.44]; $P<.001$ ). However, after adjustment for this factor, the effect of HCV infection on having an increase in either the absolute CD4 cell count (AHR, 1.00 [95\% CI, 0.86-1.17]) or the CD4 cell fraction (AHR, 1.04 [95\% CI, 0.81-1.33]) became nonsignificant.

The effects of outcomes in both the absolute CD4 cell count and the CD4 cell fraction examined as continuous repeated measures in the multivariate mixed-effects linear regression analysis are summarized in tables 3 and 4 . Table 3 displays the results (coefficients, SEs, and $P$ values) of the model, whereas table 4 provides the interpreted results from the adjusted analyses, calculated using the coefficient estimates presented in table 3. Table 4 also presents the unadjusted median changes.

In the adjusted analysis of the absolute CD4 cell counts, although both HCV antibody-positive and HCV antibody-negative patients had statistically significant increases, HCV antibody-positive patients had an average increase of 20 cells $/ \mathrm{mm}^{3}$, compared with an average increase of 75 cells $/ \mathrm{mm}^{3}$ in HCV antibody-negative patients. Even after the analysis was restricted to patients who were $\geqslant 95 \%$ adherent to ART, HCV antibodypositive patients had an average increase of 70 cells $/ \mathrm{mm}^{3}$, compared with an average increase of 104 cells $/ \mathrm{mm}^{3}$ in HCV antibody-negative patients. The difference in adjusted increases in the absolute CD4 cell count between HCV antibody-positive and HCV antibody-negative patients remained stable across the baseline absolute CD4 cell count strata (table 4).

The multivariate mixed-effect linear regression analysis of 
Table 2. Unadjusted and adjusted factors associated with increases in CD4 cell responses.

\begin{tabular}{|c|c|c|c|c|}
\hline Measurement, factor & $\begin{array}{c}\text { Unadjusted } \\
\text { hazard ratio } \\
(95 \% \mathrm{Cl})\end{array}$ & $P$ & $\begin{array}{c}\text { Adjusted } \\
\text { hazard ratio } \\
(95 \% \mathrm{Cl})\end{array}$ & $P$ \\
\hline \multicolumn{5}{|l|}{ Increase of $\geqslant 75$ cells $/ \mathrm{mm}^{3}$ in absolute CD4 cell count } \\
\hline HCV antibody status (positive vs. negative) & $0.68(0.59-0.78)$ & $<.001$ & $0.84(0.72-0.98)$ & .030 \\
\hline$\geqslant 95 \%$ adherent to ART (yes vs. no) & $2.15(1.84-2.51)$ & $<.001$ & $1.93(1.64-2.28)$ & $<.001$ \\
\hline No. of CD4 cell measurements & $1.08(1.05-1.12)$ & $<.001$ & $1.06(1.02-1.09)$ & .002 \\
\hline Baseline pVL (per $\log _{10}$ copies $/ \mathrm{mL}$ ) & $1.26(1.07-1.49)$ & .006 & $1.30(1.10-1.54)$ & .003 \\
\hline Baseline absolute CD4 cell count (per $100-$ cell/ $/ \mathrm{mm}^{3}$ increase) & $1.00(0.97-1.04)$ & .27 & $0.99(0.96-1.03)$ & .64 \\
\hline Sex (male vs. female) & $1.70(1.34-2.17)$ & .001 & $1.30(1.01-1.67)$ & .044 \\
\hline Age (per 10-year increase) & $1.06(0.98-1.15)$ & .13 & $0.97(0.90-1.06)$ & .52 \\
\hline AIDS diagnosis at baseline (yes vs. no) & $1.06(0.86-1.31)$ & .59 & $0.85(0.68-1.07)$ & .17 \\
\hline Started ART with PI (vs. NNRTI) & $0.99(0.85-1.15)$ & .88 & $1.01(0.86-1.18)$ & .90 \\
\hline \multicolumn{5}{|l|}{ Increase of $\geqslant 10 \%$ in $C D 4$ cell fraction } \\
\hline HCV antibody status (positive vs. negative) & $0.76(0.61-0.96)$ & .021 & $0.89(0.70-1.14)$ & .36 \\
\hline$\geqslant 95 \%$ adherent to ART (yes vs. no) & $2.00(1.53-2.58)$ & $<.001$ & $1.84(1.38-2.44)$ & $<.001$ \\
\hline No. of CD4 cell fraction measurements & $1.09(1.04-1.14)$ & .001 & $1.08(1.02-1.14)$ & .008 \\
\hline Baseline $\mathrm{pVL}\left(\right.$ per $\log _{10}$ copies $/ \mathrm{mL}$ ) & $1.72(1.26-2.34)$ & $<.001$ & $1.95(1.40-2.72)$ & $<.001$ \\
\hline Baseline CD4 cell fraction (per $5 \%$ increase) & $0.99(0.94-1.05)$ & .74 & $1.02(0.96-1.08)$ & .55 \\
\hline Sex (male vs. female) & $1.16(0.80-1.70)$ & .44 & $0.92(0.62-1.37)$ & .69 \\
\hline Age (per 10-year increase) & $0.95(0.84-1.08)$ & .44 & $0.90(0.79-1.02)$ & .16 \\
\hline AIDS diagnosis at baseline (yes vs. no) & $0.85(0.60-1.22)$ & .38 & $0.77(0.52-1.12)$ & .24 \\
\hline Started ART with PI (vs. NNRTI) & $0.89(0.70-1.13)$ & .33 & $0.89(0.69-1.14)$ & .35 \\
\hline
\end{tabular}

NOTE. ART, antiretroviral therapy; $\mathrm{HCV}$, hepatitis $\mathrm{C}$ virus; NNRTI, nonnucleoside reverse transcriptase inhibitor; PI, protease inhibitor; $\mathrm{pVL}$, plasma viral load.

the CD4 cell fraction showed similar results: HCV antibodypositive patients had an average increase of $1.1 \%$, compared with an average increase of $4.4 \%$ in HCV antibody-negative patients. After the analysis was restricted to patients who were $\geqslant 95 \%$ adherent to ART, HCV antibody-positive patients had an average increase of $2.8 \%$, and HCV antibody-negative patients had an average increase of $3.8 \%$.

\section{DISCUSSION}

Our results suggest that $\mathrm{HCV}$ infection has an independent effect on the immunologic response to ART over time and that the baseline absolute CD4 cell count does not significantly alter the magnitude of the $\mathrm{CD} 4$ cell response when measured either in absolute numbers or as a percentage of the $\mathrm{T}$ cell population. Our findings support those of others $[8,30,31]$. The Swiss HIV Cohort Study reported that HCV infection predicted a longer time to an increase of at least 50 cells $/ \mathrm{mm}^{3}$ in the CD4 cell count after initiation of ART [8]. Using linear regression analysis, an Italian cohort found that HCV-positive patients had a smaller increase in the CD4 cell count than did HCVnegative patients [30]. Our data are in contrast with those from studies that found that HCV infection had little or no effect on the CD4 cell response after initiation of ART [9-12, 32]. Sulkowski et al. found that HIV/HCV-coinfected patients had a statistically higher median $\mathrm{CD} 4$ cell fraction at baseline than did HCV-negative patients but found no evidence that HCV infection altered either the absolute CD4 cell count or the CD4 cell fraction [11]. A study of the HIV-Netherlands Australia Thailand cohort found that mean increases in the CD4 cell count were significantly lower in HCV-positive patients than in HCV-negative patients at week 4 but that the differences were not present by week 48 [33].

Our analysis has several strengths. First, our sample was drawn from a large population-based program, making our data more generalizable than those from clinic-based studies, cohort studies, or clinical trials. Second, we were able to account for the confounding effect of adherence to ART, through statistical adjustment and restriction based on our adherence measure, as well as through controlling for $\mathrm{pVL}$ response over time. This enabled us to adjust for any differences in $\mathrm{pVL}$ trajectories between HCV antibody-positive and HCV antibody-negative patients. Our finding that using time-updated pVL removed the effect of HCV infection in Cox proportional hazards analysis but not in multivariate mixed-effects linear regression analysis suggests that Cox models may be insufficiently sensitive for detecting differences in a continuous outcome (CD4 cells) that is artificially dichotomized, as is required in time-to-event analyses, and may explain, in part, some of the disparity in the findings in the literature. Third, by using both repeated measures and time-to-event analyses and by studying outcomes in both absolute CD4 cell counts and CD4 cell fractions, we were able to elucidate some of the complexities in analyzing the im- 
Table 3. Multivariate mixed-effects linear regression analysis of the impact that hepatitis $\mathrm{C}$ virus (HCV) infection has on CD4 cell responses.

\begin{tabular}{|c|c|c|}
\hline Effect & $\begin{array}{c}\text { Coefficient } \\
\text { estimate } \pm \text { SE }\end{array}$ & $P$ \\
\hline \multicolumn{3}{|l|}{ Increase in absolute CD4 cell count } \\
\hline Intercept & $88.09 \pm 21.51$ & $<.001$ \\
\hline Difference in absolute CD4 cell count at baseline by HCV antibody status & $2.50 \pm 9.34$ & .79 \\
\hline In HCV antibody-negative patients (per 4 weeks) & $6.26 \pm 0.77$ & $<.001$ \\
\hline In HCV antibody-positive patients (per 4 weeks) & $-4.61 \pm 1.13$ & $<.001$ \\
\hline Age & $-0.09 \pm 0.43$ & .83 \\
\hline Started ART with PI (vs. NNRTI) & $16.64 \pm 8.18$ & .04 \\
\hline Male (vs. female) & $16.77 \pm 11.99$ & .16 \\
\hline AIDS at baseline (vs. no AIDS) & $-7.91 \pm 10.78$ & $<.001$ \\
\hline \multicolumn{3}{|l|}{ pVL over time (vs. $<500$ copies $/ \mathrm{mL}$ ) } \\
\hline 500-20,000 copies/mL & $-25.85 \pm 5.46$ & $<.001$ \\
\hline$>20,000$ copies $/ \mathrm{mL}$ & $-94.32 \pm 6.83$ & $<.001$ \\
\hline \multicolumn{3}{|l|}{ Increase in absolute CD4 cell count in patients $\geqslant 95 \%$ adherent to ART } \\
\hline Intercept & $109.03 \pm 27.78$ & $<.001$ \\
\hline Difference in absolute CD4 cell count at baseline by HCV antibody status & $-1.54 \pm 11.55$ & .89 \\
\hline In HCV antibody-negative patients (per 4 weeks) & $8.63 \pm 0.85$ & $<.001$ \\
\hline In HCV antibody-positive patients (per 4 weeks) & $-2.80 \pm 1.40$ & .05 \\
\hline Age & $-0.75 \pm 0.54$ & .16 \\
\hline Started ART with PI (vs. NNRTI) & $15.36 \pm 10.25$ & .13 \\
\hline Male (vs. female) & $9.08 \pm 18.04$ & .61 \\
\hline AIDS at baseline (vs. no AIDS) & $-6.02 \pm 13.20$ & 65 \\
\hline \multicolumn{3}{|l|}{ pVL over time (vs. $<500$ copies $/ \mathrm{mL}$ ) } \\
\hline 500-20,000 copies/mL & $-7.10 \pm 6.50$ & .28 \\
\hline$>20,000$ copies $/ \mathrm{mL}$ & $-72.62 \pm 11.19$ & $<.001$ \\
\hline \multicolumn{3}{|l|}{ Increase in CD4 cell fraction } \\
\hline Intercept & $6.51 \pm 0.95$ & $<.001$ \\
\hline Difference in CD4 cell fraction at baseline by HCV antibody status & $0.37 \pm 0.38$ & .33 \\
\hline In HCV antibody-negative patients (per 4 weeks) & $0.24 \pm 0.03$ & $<.001$ \\
\hline In HCV antibody-positive patients (per 4 weeks) & $-0.15 \pm 0.04$ & .001 \\
\hline Age & $-0.01 \pm 0.02$ & .43 \\
\hline Started ART with PI (vs. NNRTI) & $0.45 \pm 0.35$ & .20 \\
\hline Male (vs. female) & $0.06 \pm 0.53$ & .91 \\
\hline AIDS at baseline (vs. no AIDS) & $-1.21 \pm 0.49$ & .01 \\
\hline \multicolumn{3}{|l|}{ pVL over time (vs. $<500$ copies $/ \mathrm{mL}$ ) } \\
\hline 500-20,000 copies/mL & $-1.23 \pm 0.20$ & $<.001$ \\
\hline$>20,000$ copies $/ \mathrm{mL}$ & $-4.62 \pm 0.26$ & $<.001$ \\
\hline \multicolumn{3}{|l|}{ Increase in CD4 cell fraction in patients $\geqslant 95 \%$ adherent to ART } \\
\hline Intercept & $6.30 \pm 1.15$ & $<.001$ \\
\hline Difference in CD4 cell fraction at baseline by HCV antibody status & $0.70 \pm 0.45$ & .12 \\
\hline In HCV antibody-negative patients (per 4 weeks) & $0.32 \pm 0.03$ & $<.001$ \\
\hline In HCV antibody-positive patients (per 4 weeks) & $-0.09 \pm 0.05$ & .066 \\
\hline Age & $-0.03 \pm 0.02$ & .10 \\
\hline Started ART with PI (vs. NNRTI) & $0.43 \pm 0.41$ & .30 \\
\hline Male (vs. female) & $0.12 \pm 0.74$ & .87 \\
\hline AIDS at baseline (vs. no AIDS) & $-0.74 \pm 0.54$ & .17 \\
\hline \multicolumn{3}{|l|}{ pVL over time (vs. $<500$ copies $/ \mathrm{mL}$ ) } \\
\hline 500-20,000 copies/mL & $-0.58 \pm 0.23$ & .01 \\
\hline$>20,000$ copies $/ \mathrm{mL}$ & $-3.83 \pm 0.40$ & $<.001$ \\
\hline
\end{tabular}

NOTE. ART, antiretroviral therapy; NNRTI, nonnucleoside reverse transcriptase inhibitor; PI, protease inhibitor; $p V L$, plasma viral load. 
Table 4. CD4 cell responses to initiation of antiretroviral therapy in hepatitis C virus (HCV) antibody-positive and HCV antibodynegative patients, stratified by baseline CD4 cell count.

\begin{tabular}{|c|c|c|c|}
\hline & $\begin{array}{l}\text { HCV antibody-positive } \\
\text { patients }\end{array}$ & $\begin{array}{l}\text { HCV antibody-negative } \\
\text { patients }\end{array}$ & $P$ \\
\hline \multicolumn{4}{|c|}{ Change in CD4 cell count, median (IQR), no. of cells } \\
\hline Total cohort & $50(-20$ to 160$)$ & 140 (50 to 240$)$ & $<.001$ \\
\hline Baseline CD4 cell count $\leqslant 200$ cells $/ \mathrm{mm}^{3}$ & $50(0$ to 50$)$ & $140(50$ to 200$)$ & .002 \\
\hline Baseline CD4 cell count $<350$ cells $/ \mathrm{mm}^{3}$ & $60(0$ to 160$)$ & 140 (40 to 210$)$ & $<.001$ \\
\hline Baseline CD4 cell count $\geqslant 350$ cells $/ \mathrm{mm}^{3}$ & $30(-80$ to 170$)$ & $160(60$ to 290$)$ & $<.001$ \\
\hline \multicolumn{4}{|c|}{ Adjusted average increase in CD4 cell count, no. of cells } \\
\hline Total cohort & 20 & 75 & \\
\hline Baseline CD4 cell count $\leqslant 200$ cells $/ \mathrm{mm}^{3}$ & 36 & 90 & \\
\hline Baseline CD4 cell count $<350$ cells $/ \mathrm{mm}^{3}$ & 31 & 86 & \\
\hline Baseline CD4 cell count $\geqslant 350$ cells $/ \mathrm{mm}^{3}$ & 11 & 57 & \\
\hline \multicolumn{4}{|c|}{$\begin{array}{l}\text { Adjusted average increase in CD4 cell count in patients } \geqslant 95 \% \text { adherent } \\
\text { to ART, no. of cells }\end{array}$} \\
\hline Total cohort & 70 & 104 & \\
\hline Baseline CD4 cell count $\leqslant 200$ cells $/ \mathrm{mm}^{3}$ & 63 & 103 & \\
\hline Baseline CD4 cell count $<350$ cells $/ \mathrm{mm}^{3}$ & 72 & 109 & \\
\hline Baseline CD4 cell count $\geqslant 350$ cells $/ \mathrm{mm}^{3}$ & 68 & 94 & \\
\hline \multicolumn{4}{|l|}{ Median (IQR) change in CD4 cell fraction, \% } \\
\hline Total cohort & $2(-1.7$ to 7$)$ & $6(2$ to 10$)$ & $<.001$ \\
\hline Baseline CD4 cell count $\leqslant 200$ cells $/ \mathrm{mm}^{3}$ & $1(-2$ to 7$)$ & 5 (3 to 10$)$ & $<.001$ \\
\hline Baseline CD4 cell count $<350$ cells $/ \mathrm{mm}^{3}$ & $2(-1$ to 8$)$ & $6(2$ to 10$)$ & $<.001$ \\
\hline Baseline CD4 cell count $\geqslant 350$ cells $/ \mathrm{mm}^{3}$ & $2(-2$ to 6$)$ & $6(2$ to 10$)$ & $<.001$ \\
\hline \multicolumn{4}{|l|}{ Adjusted change in CD4 cell fraction, \% } \\
\hline Total cohort & 1.1 & 4.4 & \\
\hline Baseline CD4 cell count $\leqslant 200$ cells $/ \mathrm{mm}^{3}$ & 0.48 & 4.0 & \\
\hline Baseline CD4 cell count $<350$ cells $/ \mathrm{mm}^{3}$ & 1.1 & 3.5 & \\
\hline Baseline CD4 cell count $\geqslant 350$ cells $/ \mathrm{mm}^{3}$ & 1.3 & 1.9 & \\
\hline \multicolumn{4}{|c|}{ Adjusted change in CD4 cell fraction in patients $\geqslant 95 \%$ adherent to ART, \% } \\
\hline Total cohort & 2.8 & 3.8 & \\
\hline Baseline CD4 cell count $\leqslant 200$ cells $/ \mathrm{mm}^{3}$ & 2.5 & 4.3 & \\
\hline Baseline CD4 cell count $<350$ cells $/ \mathrm{mm}^{3}$ & 3.0 & 4.3 & \\
\hline Baseline CD4 cell count $\geqslant 350$ cells $/ \mathrm{mm}^{3}$ & 2.5 & 3.1 & \\
\hline
\end{tabular}

NOTE. For adjusted models, see table 3.

munologic response to ART in $\mathrm{HIV} / \mathrm{HCV}$-coinfected patients. Our results were robust to different random effects (patient ID, time since initiation of ART, and baseline absolute CD4 cell count) and were independent of the number of CD4 cell measurements in HCV antibody-positive and HCV antibody-negative patients. Finally, our analyses were based on previously ARTnaive patients initiating ART with highly potent regimens and did not include patients initiating triple-nucleoside regimens.

The results of the present study could also be affected by several potential limitations. First, our measure of adherence to ART is a proxy. However, it has been validated and has been shown to be highly predictive of both virologic response [27] and survival [28, 29]. Second, the number of analyses conducted may have predisposed the occurrence of a type I error. Third, researchers at the British Columbia Centre for Excellence in HIV/AIDS have previously shown that patients who are not treated for HIV infection, in spite of being medically eligible for treatment, are substantially different sociodemographically from those who receive treatment, and these untreated patients may be more likely to be infected with HCV. This situation could have led to a selection bias in the study population in spite of its population-based nature [34] and could mean that our findings are conservative estimates, because increased numbers of $\mathrm{HCV} / \mathrm{HIV}$-coinfected patients would increase our power to detect differences. Fourth, because we did not have data on the hepatitis B serostatus of these patients, we were unable to account for the effects of chronic hepatitis B virus infection. Finally, these analyses were based on the HCV antibody status of patients and were not validated by tests for the detection of HCV RNA.

The damage caused by chronic HCV infection is not believed to be the consequence of direct destruction of hepatic cells by the virus but from an intermediate immune response that is large enough to induce hepatic cell destruction and fibrosis but small enough that the virus is not eradicated from its reservoirs [21]. A blunted immune response in HIV/HCV-coinfected pa- 
tients may be due to the nonspecific immune stimulation driven by chronic HCV infection, or it may be that infection of immune cells by HCV could favor the depletion of CD4 cells [35, 36]. Our data support the hypothesis that HCV infection is related to smaller increases in both the absolute CD4 cell count and the CD4 cell fraction than those that occur in HCV antibody-negative patients. The differences found at baseline between absolute and fraction measurements raise the issue of CD4 cell sequestration in HIV/HCV-coinfected patients. What this could mean clinically is unknown, but further research on these issues is needed. We recommend that this future research consider markers of both the absolute CD4 cell count and the CD4 cell fraction.

The immunologic response to ART in HIV/HCV-coinfected adults is a complex issue. Our data suggest that immunologic indicators - in this case, the absolute CD4 cell count and the CD4 cell fraction-may be affected by the presence of $\mathrm{HCV}$ infection. In our study population, although there was no difference between the baseline absolute CD4 cell counts in HCV antibody-positive patients and HCV antibody-negative patients, there was a marked difference in the absolute CD4 cell counts after initiation of ART. In contrast, although there was a significant difference at baseline in the CD4 cell fractions, depending on the presence or absence of HCV infection, the effect that HCV infection had on the CD4 cell fraction was less pronounced. In the present study, the baseline absolute CD4 cell count appeared to have no consistent effect.

\section{Acknowledgments}

We thank the staff of the John Ruedy Immunodeficiency Clinic at St. Paul's Hospital in Vancouver; the staff of the HIV/AIDS Drug Treatment Programme at the British Columbia Centre for Excellence in HIV/AIDS; the patients, whose lives formed the basis of the analysis; Gerhard Gillman, for assistance; and Matthias Egger, for support.

Financial support. Michael Smith Foundation for Health Research (doctoral fellowship to P.B. and Senior Scientist award to R.S.H.); Canadian Institutes for Health Research (doctoral and postdoctoral fellowships to P.B.).

\section{References}

1. Hogg R, Yip B, Kully C, Craib K, O’Shaughnessy M, Schechter M, et al. Improved survival among HIV-infected patients after initiation of triple-drug antiretroviral regimens. CMAJ 1999; 160:659-65.

2. Hogg R, Heath K, Yip B, Craib K, O’Shaughnessy M, Schechter M, et al. Improved survival among HIV-infected individuals following initiation of antiretroviral therapy. JAMA 1998;279:450-4.

3. Palella FJ Jr, Delaney KM, Moorman AC, Loveless MO, Fuhrer J, Satten GA, et al. Declining morbidity and mortality among patients with advanced human immunodeficiency virus infection. HIV Outpatient Study Investigators. N Engl J Med 1998;338:853-60.

4. Hall C, Charlebois ED, Hahn JA, Moss AR, Bangsberg DR. Hepatitis C virus infection in San Francisco's HIV-infected urban poor: high prevalence but low treatment rates. J Gen Intern Med 2004; 19:357-65.

5. Patrick DM, Tyndall MW, Cornelisse PG, Li K, Sherlock CH, Rekart ML, et al. Incidence of hepatitis $\mathrm{C}$ virus infection among injection drug users during an outbreak of HIV infection. CMAJ 2001; 165:889-95.
6. Soriano V, Sulkowski M, Bergin C, Hatzakis A, Cacoub P, Katlama C, et al. Care of patients with chronic hepatitis $\mathrm{C}$ and HIV co-infection: recommendations from the HIV-HCV International Panel. AIDS 2002; 16:813-28.

7. Yokozaki S, Takamatsu J, Nakano I, Katano Y, Toyoda H, Hayashi K, et al. Immunologic dynamics in hemophiliac patients infected with hepatitis $C$ virus and human immunodeficiency virus: influence of antiretroviral therapy. Blood 2000; 96:4293-9.

8. Greub G, Ledergerber B, Battegay M, Grob P, Perrin L, Furrer H, et al. Clinical progression, survival, and immune recovery during antiretroviral therapy in patients with HIV-1 and hepatitis C virus coinfection: the Swiss HIV Cohort Study. Lancet 2000;356:1800-5.

9. Klein $\mathrm{MB}$, Lalonde $\mathrm{RD}$, Suissa $\mathrm{S}$. The impact of hepatitis $\mathrm{C}$ virus coinfection on HIV progression before and after highly active antiretroviral therapy. J Acquir Immune Defic Syndr 2003; 33:365-72.

10. Melvin D, Lee J, Belsey E, Arnold J, Murphy R. The impact of coinfection with hepatitis $\mathrm{C}$ virus and HIV on the tolerability of antiretroviral therapy. AIDS 2000; 14:463-5.

11. Sulkowski MS, Moore RD, Mehta SH, Chaisson RE, Thomas DL. Hepatitis C and progression of HIV disease. JAMA 2002; 288:199-206.

12. Chung R, Evans S, Yang Y, Theodore D, Valdez H, Clark R, et al. Immune recovery is associated with persistent rise in hepatitis $C$ virus RNA, infrequent liver flares, and is not impaired by hepatitis $\mathrm{C}$ virus in co-infected subjects. AIDS 2002; 16:1915-23.

13. Yeni PG, Hammer SM, Carpenter CC, Cooper DA, Fischl MA, Gatell JM, et al. Antiretroviral treatment for adult HIV infection in 2002: updated recommendations of the International AIDS Society-USA Panel. JAMA 2002; 288:222-35.

14. Hilleman MR. Strategies and mechanisms for host and pathogen survival in acute and persistent viral infections. Proc Natl Acad Sci USA 2004; 101(Suppl 2):14560-6.

15. Neau D, Galperine T, Legrand E, Pitard V, Neau-Cransac M, Moreau JF, et al. T-lymphocyte populations in hepatitis $\mathrm{C}$ and HIV co-infected patients treated with interferon-alfa-2a and ribavirin. HIV Med 2003;4: $120-6$.

16. Soriano V, Puoti M, Sulkowski M, Mauss S, Cacoub P, Cargnel A, et al. Care of patients with hepatitis C and HIV co-infection. AIDS 2004; 18:1-12.

17. Perez-Olmeda M, Rios P, Nunez M, Garcia-Samaniego J, Romero M, Soriano V. Virological characteristics of hepatitis $\mathrm{C}$ virus infection in HIV-infected individuals with chronic hepatitis C: implications for treatment. AIDS 2002; 16:493-5.

18. Serfaty L, Costagliola D, Wendum D, et al. Impact of early-untreated HIV infection on chronic hepatitis $C$ in intravenous drug users: a casecontrol study. AIDS 2001; 15:2011-6.

19. Sulkowski MS, Thomas DL. Hepatitis C in the HIV-infected patient. Clin Liver Dis 2003; 7:179-94.

20. Torriani FJ, Rodriguez-Torres M, Rockstroh JK, et al. Peginterferon alfa-2a plus ribavirin for chronic hepatitis $\mathrm{C}$ virus infection in HIVinfected patients. N Engl J Med 2004; 351:438-50.

21. Poynard T, Yuen MF, Ratziu V, Lai CL. Viral hepatitis C. Lancet 2003; 362:2095-100.

22. Flamm S. Chronic hepatitis C virus infection. JAMA 2003; 289:2413-7.

23. British Columbia Centre for Excellence in HIV/AIDS. Therapeutic guidelines for the treatment of HIV/AIDS and related conditions. Vancouver: British Columbia Centre for Excellence in HIV/AIDS, 1999, 2001.

24. Carpenter C, Fischl M, Hammer S, et al. Antiretroviral therapy for HIV infection in 1996. JAMA 1996; 276:146-54.

25. Carpenter C, Fischl M, Hammer S, et al. Antiretroviral therapy for HIV infection in 1997. JAMA 1997; 277:1962-9.

26. Carpenter C, Cooper D, Fischl M, et al. Antiretroviral therapy in adults: updated recommendations of the International AIDS Society-USA Panel. JAMA 2000; 283:381-91.

27. Low-Beer S, Yip B, O’Shaughnessy MV, Hogg RS, Montaner JS. Adherence to triple therapy and viral load response. J Acquir Immune Defic Syndr 2000;23:360-1. 
28. Wood E, Hogg RS, Yip B, Harrigan PR, O’Shaughnessy MV, Montaner JS. Is there a baseline CD4 cell count that precludes a survival response to modern antiretroviral therapy? AIDS 2003; 17:711-20.

29. Hogg RS, Heath K, Bangsberg D, Yip B, Press N, O’Shaughnessy MV, et al. Intermittent use of triple-combination therapy is predictive of mortality at baseline and after 1 year of follow-up. AIDS 2002; 16:1051-8.

30. De Luca A, Bugarini R, Lepri AC, Puoti M, Girardi E, Antinori A, et al. Coinfection with hepatitis viruses and outcome of initial antiretroviral regimens in previously naive HIV-infected subjects. Arch Intern Med 2002; 162:2125-32.

31. Zala C, Patterson P, Ochoa C, Krolewiecki A, Federico R, Quercia H, et al. The impact of the hepatitis $\mathrm{C}$ virus on $\mathrm{CD} 4-\mathrm{T}$ cell response postinitiation of HAART among patients enrolled in clinical trials [abstract 817]. In: Program and abstracts of the 11th Conference on Retroviruses and Opportunistic Infections (San Francisco). Alexandria, VA: Foundation for Retrovirology and Human Health, 2004.

32. Aceti A, Pasquazzi C, Zechini B, De Bac C. Hepatotoxicity development during antiretroviral therapy containing protease inhibitors in patients with HIV: the role of hepatitis B and C virus infection. J Acquir Immune Defic Syndr 2002; 29:41-8.

33. Law WP, Duncombe CJ, Mahanontharit A, et al. Impact of viral hepatitis co-infection on response to antiretroviral therapy and HIV disease progression in the HIV-NAT cohort. AIDS 2004; 18:1169-77.

34. Wood E, Montaner J, Tyndall M, Schechter M, O’Shaughnessy M, Hogg R. Prevalence and correlates of untreated human immunodeficiency virus type 1 infection among persons who have died in the era of modern antiretroviral therapy. J Infect Dis 2003; 188:1164-70.

35. Soriano V, Miro JM, Garcia-Samaniego J, et al. Consensus conference on chronic viral hepatitis and HIV infection: updated Spanish recommendations. J Viral Hepat 2004; 11:2-17.

36. Wendelbo O, Bruserud O. Functional evaluation of proliferative T cell responses in patients with severe $\mathrm{T}$ lymphopenia: characterization of optimal culture conditions and standardized activation signals for a simple whole blood assay. J Hematother Stem Cell Res 2003; 12:525-35. 